\title{
Ignez é morta: reflexões acerca da clausura para as Irmãs clarissas (séculos XIII ao XVIII)
}

\author{
Ana Cristina Pereira Lage ${ }^{1}$ (iD 0000-0003-2716-6847 \\ Terezinha Oliveira $^{2}$ (iD 0000-0001-5349-1059 \\ 'Universidade Federal dos Vales do Jequitinhonha e MucuSri, Diamantina, MG, Brasil. \\ 39100-000.coord.historia@ufvjm.edu.br \\ 2Universidade Estadual de Maringá, Maringá, PR, Brasil. 87020-900. sec-dfe@uem.br
}

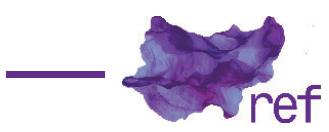

Resumo: Pretendemos analisar alguns embates de gênero no interior da lgreja Católica para compreender a institucionalização da clausura feminina no século XIII. A ideia de morte para as coisas terrenas, quando as mulheres ingressavam nas clausuras e passavam à condição de religiosas clarissas, é debatida por meio de documentos do período moderno nos conventos de Portugal e da América Portuguesa. São verificadas ainda as representações discursivas acerca da clausura e a percepção de desvios claustrais que propiciavam mulheres com religiosidade diversa do instituído pela lgreja e pelas relações patriarcais.

Palavras-chave: Religiosidade Cristã; conventos; clausuras; clarissas.

Ignez is Dead: Reflections about Enclosure for Clarisse Sisters (13th to 18th centuries)

Abstract: This article aims at analyzing some gender discussions inside the Catholic Church to the understanding of the institutionalization of female enclosure by the Christian Church in the XIIIth century. The idea of death to earthly subjects when women entered into enclosure and turned into the condition of religious Clarrisses is treated by analyzing documents from the modern period in the convents of Portugal and the Portuguese America. This discursive representations about the enclosures and the perception of cloistral deviations which permitted women with a religiosity diverse from the instituted by the Church and by the patriarchal relations are also treated.

Keywords: Christian religiosity; Convents; Enclosures; Clarisses.

Ignez es muerta: reflexiones sobre el claustro de las clarisas (siglos XIII al XVIII)

Resumen: Se pretende analizar algunos choques de género dentro de la lglesia Católica para comprender la institucionalización del claustro femenino en el siglo XIII. La idea de la muerte por las cosas terrenales, cuando las mujeres entraban en los claustros y pasaban a la condición de Clarisas, se debate a través de documentos de la época moderna en los conventos de Portugal y América portuguesa. También se verifican las representaciones discursivas sobre el claustro y la percepción de desviaciones en los claustros que dotaron a las mujeres de una religiosidad diferente a la establecida por la Iglesia y las relaciones patriarcales.

Palabras clave: Religiosidad Cristiana; Conventos; Claustros; Clarisas.

Neste artigo não pretendemos trabalhar com a história da célebre portuguesa Inês de Castro, aquela citada na obra Os Lusíadas (Luís de CAMÕES, 1572, p. 58-62) e que deu origem à expressão 'Inês é morta' (Rodrigo ZAGNI, 2008).' Referimo-nos aqui à outra portuguesa Ignez da Trindade - que viveu no século XVII e não morreu fisicamente no momento em que se recolheu ao Convento de Santa Clara da cidade de Évora, mas discursivamente passou a ser

' A história de Inês de Castro gerou a expressão que caiu no gosto popular e cujo sentido demonstra a impossibilidade de efetivar algumas ações. Esta Inês faleceu em 1355, quando o rei português D. Afonso IV (1325-1357) mandou executá-la, pois era amante de seu filho. Quando o filho tornou-se rei - D. Pedro I (1357-1367) - e finalmente poderia se casar com a sua amada, lamentou-se com a expressão: "Inês é morta!" (ZAGNI, 2008). 
considerada morta para o mundo terreno ao se tornar uma religiosa clarissa. Antes de tudo, é preciso compreender que o documento aqui analisado, o sermão proferido no momento em que deixou de ser noviça e passou ao estado de freira, foi escrito por um religioso, Frei Luis de Santa Catarina (1673), o qual apresenta um discurso dominante por parte da Igreja Católica naquele momento acerca do universo da clausura feminina. Esse discurso buscava conformar e adaptar as mulheres que adentravam nos conventos para um jeito adequado de ser religiosa aos olhos da Igreja Católica. Dizia então:

E Ignez morre amante prometendo em esta profissão o enterrar-se viva, e viver como morta, que a Cela verdadeiramente religiosa, não é casa para se viver, sepultura sim para se enterrar. [...] Estado onde se não vê, não se ouve, não se fala, não é estado de vivos, é vida de mortos, e como esta é obrigação de uma religiosa, o Convento donde se recolhe, não é casa para se viver, é sepultura para se enterrar [...] morte é, a que se destina lgnez, seguindo a seu Esposo sacramentado² (SANTA CATARINA, 1673).

Segundo a visão do autor, quando Ignez da Trindade passava ao estado de religiosa clarissa, desposava Jesus Cristo e se tornava então um ser que não poderia mais ouvir, falar ou ver coisas do mundo exterior. A partir de então, a sua vida seria mais próxima do mundo dos mortos do que dos vivos e o Convento de Santa Clara de Évora a sua sepultura. Mas será que Ignez e as demais clarissas realmente se consideravam mortas e enterradas no convento? Ou a representação da morte da religiosa fazia parte de um discurso masculino para controlar 0 universo claustral feminino?

Em busca de algumas respostas, neste artigo, pretendemos, inicialmente, dialogar com as questões de gênero e as suas relações com a religiosidade das mulheres enclausuradas; em segundo lugar, buscaremos analisar a necessidade da constituição das clausuras para o universo feminino religioso; em um terceiro momento, dialogaremos com a documentação pertinente que institui a clausura para as clarissas; por fim, apresentaremos alguns documentos que apontam pistas para a percepção e a vivência do claustro pelas referidas freiras nos conventos de Portugal e da América Portuguesa nos séculos XVII e XVIII.

\section{Intercessōes entre gênero e religiosidade das mulheres enclausuradas}

Pensar as interligações entre o feminino e o religioso só é possível a partir da compreensão das relações de gênero na história, especialmente quando trabalhamos com fontes que apresentam discursos produzidos por homens acerca das mulheres, uma vez que, desde a Antiguidade, a maioria dos escritores cristãos insistiu em afirmar a submissão feminina com relação ao homem.

[...] a maior parte desta produção literária foi escrita por homens celibatários, o que sem dúvida terminou por refletir suas convicções, desejos e fobias com relação à mulher. Embora estas construções teóricas tenham influenciado de alguma maneira os comportamentos sociais, não se pode incorporá-las à construção histórica sem levar em consideração a existência de outras fontes (Maria Filomena NASCIMENTO, 1997, p. 86).

A investigação das fontes produzidas nos espaços ocupados predominantemente por mulheres aponta para o relacionamento delas com a sociedade de sua época e como estas se posicionavam em suas relações de gênero. Ao definir gênero, Joan Scott (1995) propõe que este é constituído nas relações sociais, por meio das diferenças entre os sexos, como também seria uma forma de significar relações de poder. É necessário, então, distanciar-se do discurso binário, mas compreender as inter-relações entre homens e mulheres em uma determinada realidade social e as suas relações de poder. No decorrer deste artigo, pretendemos demonstrar as interrelações entre homens e mulheres religiosos, bem como as relações de poder que aconteciam no interior dos espaços conventuais.

Investigar os claustros significa lidar com microcosmos humanos que muitas vezes eram regidos externamente por determinados homens como, por exemplo, visitadores, confessores ou superiores das ordens monásticas. Por outro lado, também é necessário perceber que várias mulheres enclausuradas lutaram pelo estabelecimento de espaços independentes dessa relação com os superiores e resistiram ao domínio da influência masculina (Marie-Elisabeth HENNEAU, 2008). Muitas religiosas pertenciam aos grupos sociais dominantes e estabeleceram relações de poder no interior dos claustros ou para além deles, por meio da circulação de seus escritos. Foram mulheres fortes que utilizaram as suas práticas de escrita para demonstrar e circular os seus pensamentos, para além das proibições e contestações de seus confessores ou superiores. Em Portugal, destaca-se Sóror Maria do Céu (1658-1753), religiosa clarissa do Real Convento de Nossa Senhora da Esperança de Lisboa, que produziu uma literatura de natureza diversa,

${ }^{2}$ Este artigo apresenta a transcrição atualizada dos documentos. 
como vidas de santas e religiosas exemplares, comédias e peças teatrais (Ana HATHERLY, 1990). Na América Espanhola, podemos citar Sóror Juana Inez de la Cruz, uma mexicana carmelita de forte influência no vice-reinado da Nova Espanha, considerada a "mais notável representante da poesia feminina no século XVIII, mulher de beleza extraordinária, poetisa de grande talento e inteligência que cultivou todos os temas: desde os profanos até os autobiográficos, passando pelos discretos e conceituosos" (Margareth COSTA, 2013, p. 12).

Por muitos anos, a historiografia acerca das instituições habitadas por grupos de mulheres cristãs tratou da opressão imposta pelos homens nesses espaços, tanto com relação às reclusões forçadas, quanto na administração dos conventos. Essa perspectiva coincidiu com a emergência dos estudos de gênero na década de 1960. Atualmente, novos questionamentos historiográficos são postos, e a vocação para a religiosidade feminina é revisitada. Acreditamos que os espaços habitados por esses grupos não podem mais serem vistos como somente locais de opressão, já que muitas vezes as mulheres aí ingressavam por vontade própria, deliberavam sobre a administração, refletiam e promoviam o conhecimento intelectual, como as célebres Hildegard von Bingen (1098-1 178) e Rosvita de Gandersheim (c.935-c.973). Os conventos podem ser vistos também como locais de resistência, de liberdade intelectual e de afastamento das imposições familiares para cumprirem os definidos papéis de esposas e mães.

Desde a Antiguidade, havia uma diversidade de formas de reclusão feminina: inicialmente por meio do eremitismo individual, ou pelo encarceramento dentro do próprio espaço familiar e, finalmente, e cada vez mais, nos mosteiros ou conventos. É importante observar que a reclusão feminina no interior das casas já acontecia desde a Grécia Clássica, anterior ao cristianismo, especialmente em virtude da preservação da castidade, do silêncio e do recato (Moisés TÔRRES, 2001). Com o advento e fortalecimento do cristianismo, gradativamente surgiram espaços de recolhimento intramuros para as mulheres da nobreza romana, os quais ganharam popularidade já no século IV. Desde então, a reclusão feminina apareceu como uma forma de controle sobre a sexualidade ou penitência dos seus atos, uma vez que a mulher era considerada, aos olhos da Igreja Católica, como o centro da tentação e do pecado dos homens. Justificava-se, então, a valorização de uma vida ascética feminina como uma forma de cerceamento de uma sexualidade considerada como incontrolável (Paula DIAS, 2015). A partir desse período, Dias (2015) propõe como principais fatores para a necessidade de reclusão feminina: a sublimação da virtude; a conversão e penitência após uma vida dissoluta; a renúncia ao papel de esposa e mãe; a recusa ou prevenção da sexualidade.

A palavra clausura é derivada etimologicamente da palavra latina claudere (fechar). 0 enclausuramento seria, por conseguinte, o fechamento de indivíduos em determinado espaço. No tocante à condição religiosa, especialmente aquela monástica, isso exigiria uma distinção dos seus habitantes com relação ao restante do mundo:

Do ponto de vista histórico e literário, este isolamento essencial, associado à condição monástica, constitui a justificação primeira para as manifestações de clausura ou de emparedamento, que acompanham outras formas extremas de incorporar a solidão monástica. Trata-se de uma demonstração física e exterior de uma condição espiritual de isolamento e de fechamento, estabelecendo-se as fronteiras precisas (as mesmas que separam o espaço profano do espaço sagrado) entre o indivíduo e o mundo envolvente (DIAS, 2015, p. 12).

O enclausurado, independente do gênero sexual, seria, então, um indivíduo distinto do restante da sociedade por se distanciar das questões mundanas e públicas, mais voltado para a vida privada e, por meio de suas ações, mais próximo do mundo 'celeste'. Por esse afastamento, seriam considerados como mediadores entre os vivos e os santos por meio de suas orações. "Os monges e as religiosas eram indispensáveis à sociedade em razão de seu quase monopólio sobre a oração. A função religiosa era essencial na concepção da organização social então amplamente compartilhada" (Lester LITTLE, 2002, p. 232). Por conta deste "quase monopólio da oração', várias pessoas leigas auxiliavam economicamente os mosteiros ou conventos $e$ barganhavam um lugar no mundo celeste por conta das intercessões das orações monásticas, fato que acarretou a expansão dos espaços ao longo do período medieval (LITLLE, 2002).

Por outro lado, algumas funções nos claustros femininos só poderiam ser exercidas por homens, como a celebração de missas, de confissões ou até de visitações para a garantia da inviolabilidade dos espaços. Para além da intencionalidade, ou não, da mulher de habitar esses espaços, é importante salientar as interdições existentes para a sua ocupação de espaços públicos e a patriarcalização das funções de liderança no seio da Igreja Cristã. Carmelina Urso (2005) aponta que, embora seja possível observar alguns casos de ministério feminino no início do cristianismo, eles desapareceram ao longo da Idade Média e as funções religiosas femininas ficaram cada dia mais concentradas somente nos ambientes claustrais. As justificativas discursivas para essa diferenciação indicavam a percepção de certa 'inferioridade' feminina.

As deliberações sobre a impureza das mulheres e a sua consequente interdição aos lugares sagrados aparecem agora incorporadas em um projeto preciso que, marcando a inferioridade 
natural da mulher em todos os níveis, justificou as eliminações drásticas das diversas mulheres aos aparelhos eclesiásticos.

[...] Prevalece, no final, e torna-se oficial a teoria de que, de acordo com as escolhas apostólicas de Cristo, deve ser atribuído somente aos homens o sacerdócio (URSO, 2005, p. 81, tradução livre).

O controle do universo feminino pelo masculino no seio do cristianismo não estava restrito somente à interdição ao sacerdócio por parte das mulheres. Aquele controle também se refletia em ações no próprio ambiente de reclusão, especialmente por meio de indicações de abadessas, as regentes conventuais, e cada vez mais um maior cerceamento dos seus poderes, uma vez que é possível perceber uma abrangência gradativa dos poderes de confessores e visitadores nesses locais ao longo do período medieval (Roberto RUSCONI, 1980). Por outro lado, é importante salientar o medo da violência que assolava o Ocidente medieval anterior ao século XI, quando diversas invasões escandinavas e guerras constantes no território levavam as mulheres à busca de mosteiros e do apoio de cavaleiros e religiosos para a proteção desses espaços (Georges DUBY, 1999).

\section{A instituição da clausura feminina}

Entre os séculos XI e XIV ocorreu uma ampliação da vida religiosa feminina no Ocidente medieval. Vários fatores contribuíram para essa expansão, com destaque para o feudalismo, sistema que acarretou o aumento da população; o fortalecimento econômico; o desenvolvimento do poder político dos reis e diversas mudanças sociais e culturais. $O$ aumento populacional feminino promoveu a criação de mais espaços de reclusão, uma vez que, entre os anos 1000 e 1300, o número de mosteiros femininos nos territórios que compreendem hoje a França e a Inglaterra foi multiplicado cerca de dez vezes (Paulette L'HERMITE LECLERCQ, 2005). Por outro lado, surgiram grupos de mulheres fora dos mosteiros que também buscaram viver como nas comunidades primitivas em grupos espontâneos e outras ainda encontraram nas heresias o caminho mais adequado para vivenciar a pobreza, distantes então do domínio eclesiástico.

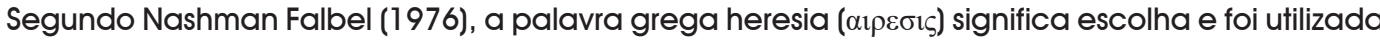
pela Igreja Cristã desde a sua fundação para identificar uma doutrina contrária à fé cristã. As heresias da antiguidade contestavam as "verdades reveladas", ou seja, os dogmas cristãos, mas o que caracteriza as heresias medievais é o seu caráter popular assentado sobre uma nova visão ética do cristianismo como religião vigente na sociedade ocidental.

Para Silvia Federici (2017), "um dos aspectos mais significativos do movimento herético é a elevada posição social que este designou às mulheres" (p. 83). Em algumas seitas heréticas, cátaros ou valdenses, as mulheres tinham possibilidades de ministrar sacramentos, pregar e batizar. As mulheres ainda formavam comunidades autônomas, como as beguinas, movimento que surgiu por volta de 1170 na atual Bélgica. Eram "mulheres religiosas que viviam sem uma regra determinada, assumindo apenas um 'propósito de vida'. Em geral, formavam comunidades, onde se dedicavam à oração, ao trabalho e a obras de assistência" (Delir BRUNELLI, 2002, p. 18). Podiam viver isoladamente, na forma eremítica, ou então em pequenas comunidades. $O$ movimento perdeu força quando buscou o reconhecimento da Igreja Católica.

Em contrapartida aos movimentos que contestavam o poder religioso, a partir do século XI, a Igreja Cristã propôs reconfigurações em seu interior. Inicialmente, a Reforma Gregoriana, empreendida pelo papa Gregório VII (1073-1085), foi responsável por ampliar o número dos espaços de reclusão feminina, mas também impôs uma maior dependência desses lugares ao domínio masculino, já que enfraqueceu o poder das abadessas nos microcosmos conventuais. Além disso, é importante salientar que a Reforma propunha uma 'volta às origens' das ordens monásticas, as quais haviam se distanciado dos seus princípios ao possuírem propriedades luxuosas e enriquecerem por meio da exploração da terra e das polpudas esmolas que recebiam (Jacques LE GOFF, 2011).

A ideia de 'volta às origens', que refletia nas contestações culturais contrárias ao grande poder econômico da Igreja Cristã, foi responsável por propiciar o surgimento dos movimentos religiosos espontâneos, tanto masculinos quanto femininos. É importante observar que esses grupos receberam mulheres de diversos segmentos sociais, o que não era usual até então, para os mosteiros e conventos, compostos em sua grande maioria por pessoas advindas da nobreza. É lógico que a expansão desses movimentos espontâneos, que se aproximavam muitas vezes de princípios heréticos, gerava tensões e fugia das tentativas de controle pela Cúria Romana.

Embora a clausura feminina já fosse uma prática desde a Antiguidade clássica, foi por intermédio da publicação da Bula Periculoso (1298), do papa Bonifácio VIII (1294-1303), que foi instituído e efetivado o 'enclausuramento perpétuo' de todas as comunidades religiosas femininas, ou seja, para se tornar uma religiosa, a mulher não poderia mais abandonar a sua clausura. O documento papal aponta para uma necessidade de moralizar os claustros, pois, naquele momento, havia certa liberdade de circulação das religiosas e de pessoas no interior dos claustros: 
É perigoso e detestável que algumas freiras negligenciem o estilo de honestidade e descaradamente abandonem a modéstia e o pudor do próprio sexo, rodeiem as casas de seculares fora do próprio mosteiro e frequentemente admitam pessoas suspeitas em suas casas (BONIFÁCIO VIII, 1298, tradução livre).

Na visão papal, as freiras optaram espontaneamente pela vida religiosa e deveriam viver como mulheres reclusas e sem contato com o mundo externo. Não poderiam, portanto, circular em outros espaços ou receber visitas nos claustros. Estabeleceu-se, então, que todas as monjas "presentes e futuras de qualquer congregação e ordem, em qualquer parte do mundo em que residam, estejam sob perpétua clausura" (BONIFÁCIO VIII, 1298, tradução livre). A partir da publicação da referida Bula, as mulheres que adentravam em um mosteiro ou convento deveriam ser enclausuradas até a morte carnal (DIAS, 2015). A saída só aconteceria em casos de doenças ou com a aprovação dos superiores da ordem religiosa. É necessário observar que a correlação do enclausuramento com a morte se fortaleceu ao longo do período medieval, sendo que o papa Urbano II (1088-1099) foi o responsável por utilizar pela primeira vez a expressão de que as freiras estavam 'mortas para o mundo', pensamento que proliferou concomitantemente com a necessidade de expansão das clausuras. "É importante frisar, que a questão da clausura é um assunto de homens, pois eram eles que se preocupavam em limitar a mobilidade das mulheres e sua relação com o mundo. Já as maiores interessadas, não eram convidadas a opinar" (Valéria SILVA, 2009, p. 15).

A instituição e o fortalecimento do enclausuramento feminino estiveram diretamente vinculados à necessidade de ampliar a dependência das mulheres que buscavam os conventos e mosteiros em relação à Cúria Romana e aos superiores das respectivas ordens monásticas. Uma vez que se distanciavam do mundo circundante e eram proibidas de circular fora dos claustros, as mulheres passavam a depender cada vez mais financeiramente de seus dotes para o ingresso nas instituições e também eram obrigadas a possuir bens para a própria sobrevivência.

O estreitamento da obrigatoriedade da clausura gerou ainda distinções e enriquecimentos no interior dos microcosmos conventuais, uma vez que, "quanto mais estreita se tornava a clausura, mais necessário e obrigatório se tornava o dote" (Jean LECLERCQ, 1980, p. 89, tradução livre). Quanto mais recursos uma recolhida apresentava no momento do seu ingresso, mais distinta se tornava no interior do claustro. Aquelas que não possuíam muitos recursos e desejavam ingressar em um convento eram inseridas, geralmente, nas atividades de trabalhos manuais e colocadas em uma categoria inferior no interior do grupo.

\section{As clarissas e a clausura}

Dentre aqueles movimentos que surgiram espontaneamente, podemos categorizar o franciscanismo do século XIII. Segundo Jacques Le Goff (2011), Francisco de Assis (11821226) deve ser considerado produto de um lugar e um momento, fruto de uma tradição dos movimentos anteriores, mas também da luta de classes entre a nobreza e a burguesia nascente das cidades italianas, fato que acarretou a ascensão de leigos e o progresso da economia monetária. Sua inovação com relação às ordens que surgiram anteriormente era a proposta da imitação direta da vida de Cristo e não da vida dos apóstolos. Raoul Manselli (1980) aponta que a sua proposta não é só pauperística, mas uma passagem a outro estado, para o qual busca o exemplo de Cristo.

Do mesmo modo configurou-se o franciscanismo feminino, uma vez que Clara de Assis (1193-1253) e suas primeiras seguidoras não intencionavam viver em mosteiros ou adentrar em uma ordem religiosa. Elas buscavam viver como Francisco, no exemplo de Cristo, por meio da pobreza, da penitência e da pregação, sendo que a sobrevivência do grupo aconteceria por meio da arrecadação de esmolas. Mas os franciscanos logo estabeleceram as diferenças pela própria sobrevivência do grupo e aceitação pela Cúria Romana: de um lado, era necessário o silêncio e o enclausuramento para as mulheres; do outro, permitia-se a fala e a itinerância para os homens. A pregação nos ambientes públicos passou a ser vetada para as mulheres, que logo foram encaminhadas para os espaços de reclusão, como o convento de São Damião, em Assis, habitado a partir de 1212 por Clara e suas seguidoras, as damianitas, ou Damas Pobres.

A perspectiva de reclusão das Damas Pobres acarretou diversas tensões, uma vez que Clara entendia que elas poderiam circular em outros ambientes por 'motivo útil', especialmente para recolher esmolas ou negociar e fundar novas obras. É importante observar que os princípios clarianos se espalharam rapidamente nos principais centros urbanos do Ocidente medieval cristão por meio da circulação por 'motivo útil' de suas seguidoras (Clara GENNARO, 1980). Embora existisse um movimento mais ampliado e anterior de religiosidade, o franciscanismo feminino tornou-se o movimento predominante no século XIII. Porém,

diante da extrema variedade, riqueza e vivacidade desses grupos, a Igreja se sentia pressionada a intervir, dar instruções, normas e uma forma unitária a um movimento que, apesar de fervoroso, tinha o risco de parecer turvo e confuso e, assim, colocar em discussão, 
entre outras coisas, o status e a posição das mulheres na Igreja e na vida religiosa em particular (GENNARO, 1980, p. 175, tradução livre).

A partir do IV Concílio de Latrão (1215), foram configuradas diversas tentativas de normatizar a vida no interior dos espaços ocupados pelas Damas Pobres. ${ }^{3}$ Todas as propostas que receberam se distanciavam dos princípios clarianos, uma vez que propunham a detenção de propriedades e a ampliação do enclausuramento. Contrariada com a questão da posse de bens, Clara solicitou ao papa Inocêncio III o 'Privilégio de Pobreza', concedido para a sua comunidade em 1228. As tensões postas para Clara estavam entre seguir a Fraternitas franciscana e as propostas encaminhadas de institucionalização das damianitas por parte do poder pontifício (Terezinha DUARTE, 2001).

A Forma de Vida proposta por Clara foi aprovada pelo papado em 9 de agosto de 1253, um dia antes de seu falecimento. É necessário compreender que Clara, no ambiente privado do claustro, demonstrava o pensamento por meio da escrita. Da sua obra, poucos documentos chegaram à atualidade: ela escreveu em latim a Forma de Vida (considerada o primeiro documento dessa natureza elaborado por uma mulher), uma benção, um testamento e algumas cartas. A sua proposta de Forma de Vida pode ser considerada um contraponto às demais tentativas de normatização do seu grupo por parte da lgreja Cristã. É importante salientar que a Forma de Vida seria um documento produzido no interior do Grupo das damianitas, e expressava os seus anseios. Ele não foi imposto pelo papado como os demais documentos. Origina-se daí, inclusive, a sua originalidade.

Uma Segunda Regra foi logo proposta para as seguidoras de Clara pelo papa Urbano IV (1263), com a intenção de proporcionar melhor direcionamento para o grupo de religiosas e diminuir a 'rigidez' da Forma de Vida de Clara (José Carlos PEDROSO, 2004). Foi nesse momento que as Damas Pobres passaram a ser denominadas clarissas, e aquelas que seguiram aquela regra foram consideradas urbanistas. Pesquisadores sobre este tema apontam que a principal diferença entre as duas regras está no alcance do voto de pobreza e a união jurídica com a Ordem de São Francisco. Assim, a Regra proposta pelo papa Urbano foi modificada e passou para o Governo de um Cardeal Protetor; além disso, impôs a obrigatoriedade do dote para a inclusão das mulheres na clausura e previu propriedades e rendas para os conventos (Fr. José Antônio PEREIRA, 2011).

Consideramos que o ponto primordial de distanciamento entre os dois documentos foi a inclusão da clausura como um quarto voto obrigatório na Regra urbanista. Quando Clara falou da clausura no capítulo XI da sua Forma de Vida, percebe-se que ela se preocupou mais em discorrer sobre o controle das portas dos conventos para proibir a circulação de pessoas leigas. "Clara se aproxima mais da concepção eremítica de São Francisco, no ideal que propunha para a Porciúncula e no que sugeriu para os eremitérios: um lugar de silêncio e de oração, mas, nunca uma clausura fechada, como chave de um ordenamento severamente ascético" (DUARTE, 2001, p. 70). Já a Regra de Urbano IV, em diversos momentos (capítulos II, III e XVIII), remete à clausura como eixo fundamental da instituição da Ordem das clarissas.

\begin{abstract}
Aquelas que professam esta vida sejam firmemente obrigadas a permanecer em clausura perpétua dentro do âmbito dos muros que constituem a clausura interior do mosteiro, a não ser que (o que Deus não permita) uma imprevisível emergência como incêndio, ataque inimigo ou coisa semelhante, não dê tempo para pedir as necessárias licenças (URBANO IV, cap. XVIII apud PEDROSO, 2004, p. 339).
\end{abstract}

Aos olhos do papa, uma vez enclausuradas, a saída era vedada para essas mulheres. Dentro dos conventos urbanistas existiria um espaço que somente seria ocupado pelas freiras, formando assim um microcosmo dentro de outro. Além disso, o papa instituiu normas e penas para as demais pessoas que ousassem adentrar nos conventos e claustros. Essa preocupação com a clausura gerou distinções e enriquecimentos nos espaços conventuais.

A partir desse momento, seguir os passos de pobreza propostos por Clara era quase impossível e as distinções sociais no interior dos grupos conventuais só se fortaleceram, pois dependiam cada vez mais dos dotes das ingressantes. A falta de recursos para os dotes gerava ainda um novo grupo no interior dos conventos: a separação entre mulheres enclausuradas e que ingressavam com dotes, geralmente chamadas de Irmãs de Coro; e aquelas serventes da casa, também chamadas de conversas ou externas, com poucos recursos, as quais eram geralmente recrutadas entre as camponesas para o serviço doméstico e inclusive poderiam circular em outros ambientes (MANSELLI, 1980). Se Clara antes propunha a recepção de mulheres com o ideal de viver em pobreza, portanto, sem distinção social, com a Regra urbanista, estas se tornavam distintas no interior do convento. Urbano IV se preocupou, inclusive, em instituir trajes bem distintos para as clarissas, especialmente acerca dos véus que deveriam portar nas cabeças: preto para as irmãs de Coro e branco para as Serventes.

${ }^{3}$ Receberam a Regra de São Bento (1219), a Forma de Vida do Cardeal Hugolino (1223) e a Forma de Vida de Inocêncio IV (1247). 


\section{A vivência na clausura das clarissas}

No Período Moderno, diversas obras foram escritas por religiosos que buscavam alinhar e uniformizar as atividades no interior dos claustros por meio dos seus discursos. Dentre os diversos escritos do padre francês Miguel Angelo Marin (1697-1767) e que circularam pelos ambientes religiosos da Europa, destaca-se a obra A perfeita religiosa (1750), a qual teve ampla difusão nos conventos portugueses após a sua tradução e publicação (1789). O referido autor inicia sua obra com a seguinte definição: "A Religiosa é uma pessoa, que renuncia solenemente ao Mundo para só se dedicar a Jesus Cristo, e a qual este Divino Mestre se digna receber em o número de suas Sagradas Esposas pela graça da vocação que lhe dá" (Miguel Angelo MARIN, 1789, p. 3). A renúncia e o total distanciamento do mundo seriam condições necessárias para alcançar o estado de perfeição e poder portar o título de esposa de Cristo: "Vós renunciastes ao Mundo pelo estado que abraçastes; é preciso consequentemente sustentar-vos nesta renunciação quando não queirais ser infiel a vossas promessas" (MARIN, 1789, p. 4). Essa renúncia só poderia acontecer por meio da "clausura que vos separe do mundo" (MARIN, 1789, p. 5).

Por sua vez, o franciscano Frei Joseph de Jesus Maria (1718, p. 89) buscou definir o que seria uma 'perfeita religiosa' clarissa urbanista portuguesa: seria a enclausurada que soubesse ler e entender o Ofício Divino em latim e, além disso, falar com Deus. É importante salientar que a perfeição só poderia ser alcançada pelas irmãs que portavam o véu preto, pois eram aquelas que possuíam o dom da leitura e participavam do Ofício Divino no Coro. Poucas seriam consideradas 'perfeitas' e tiveram as suas vidas exemplares narradas por meio de autobiografias ou biografias escritas por outras freiras ou por seus respectivos confessores. A clausura era assim definida:

É aquele sítio, ou âmbito, que se contem das portas adentro do Mosteiro, deputado da clausura, donde as freiras não podem sair, nem os seculares entrar. Digo deputado para clausura, para excluir toda a casa ou lugar do Convento que não esteja para clausura deputado, porque a deputação é circunstância necessária para a clausura (JOSEPH DE JESUS MARIA, 1718, p. 69-70).

A clausura seria, portanto, um espaço inviolável dentro de outro espaço, o mosteiro ou o convento. Algumas pessoas poderiam adentrar neste último espaço, mas somente as religiosas circulariam pelos claustros das clarissas. Este era o discurso para a definição do espaço, mas precisamos, ainda, descobrir como esses espaços foram ocupados pelas religiosas em Portugal e na América Portuguesa nos séculos XVII e XVIII.

A maioria dos conventos portugueses e aquele primeiro fundado na América Portuguesa, o Convento de Santa Clara do Desterro da Bahia (1677), receberam a Regra urbanista. Devido às peculiaridades da religiosidade lusitana, muitas instituições clarianas foram financiadas por mulheres ou homens abastados com o propósito de alcançar a salvação, pois o convento poderia ser o espaço para o seu futuro sepultamento e asseguraria a oração das religiosas pela salvação das almas dos benfeitores (Alfredo SARAMAGO, 1994). Os conventos das clarissas urbanistas constituíram-se geralmente em espaços que receberam mulheres da elite, portadoras de ricos dotes, que estavam correlacionadas às esferas políticas e religiosas locais e dos seus fundadores.

Provavelmente Ignez da Trindade fazia parte da elite portuguesa, uma vez que a sua passagem para o estado de religiosa no Convento de Santa Clara de Évora foi agraciada com um sermão escrito e proferido pelo Frei Luiz de Santa Catarina (1673), professor de Teologia no Convento de São Francisco daquela cidade. O referido sermão, que celebrava o momento da entrada de Ignez na clausura, tratava de seu 'desposório' com Jesus Cristo. Os encontros com o seu 'esposo' aconteceriam nos momentos de celebração do Ofício Divino:

Duas casas tem Soror Ignez da Trindade pera sua habitação, uma de seu Esposo, que é aquele Coro, a donde celebra estes venturosos desposórios, e a outra de sua mãe: a de seu Esposo, goza por Esposa, a de sua mãe, possui como filha; em o Coro se entrega toda ao Divino com a Oração, Contemplação, e goza as delícias de seu Esposo Sacramentado; em a casa da mãe, se entrega a ocupações de vida humana, pois diz Ignez: Esposo soberano, se cheguei venturosa, a dar-vos a mão de Esposa, não vos quero deixar um instante de meus braços [...]; não só hei de ser vossa em vossa casa, também quero ser vossa em casa de minha mãe (SANTA CATARINA, 1673, s.n.).

Na visão do frade franciscano, haveria dois espaços a serem ocupados por uma freira: o Coro, casa de Jesus Cristo, local onde ocorreria o encontro entre a religiosa e seu 'esposo' por meio da celebração do Ofício Divino; e o restante do Convento, casa de sua mãe/abadessa, espaço no qual teria suas tarefas humanas, mas sempre com os pensamentos voltados para o seu 'esposo'.

Em algumas fontes consultadas, especialmente obras escritas no interior dos conventos na forma de biografias ou autobiografias de freiras exemplares, é possível encontrar representações de conflitos nas 'relações maritais' que envolviam brigas entre os cônjuges, tentações e traições com o demônio e até conselhos e intercessões de Maria, a sogra. Tudo era acompanhado de 
visões que suscitavam questionamentos e sanções do Tribunal do Santo Ofício, pois havia uma linha muito tênue que separava o mundo sobrenatural e o imaginário da realidade vivenciada nas clausuras.

Salientamos que os espaços conventuais não eram destinados somente à oração, mas também serviam para o desenvolvimento de atividades manuais $e$, particularmente, intelectuais, uma vez que a maioria das escritoras dos séculos XVII e XVIII era enclausurada. A escrita conventual poderia ser administrativa, pessoal ou, ainda compreender as obras exemplares (biografias ou autobiografias). Lígia Bellini (2006/2007, p. 209) aponta que as obras devocionais escritas por mulheres enclausuradas em Portugal, no século XVIII, foram edições de razoável qualidade e contaram com a aprovação e patrocínio do clero, com dedicatórias para personalidades civis ou eclesiásticas e usualmente empregavam 'fórmulas de modéstia', pois as escritoras acreditavam que não eram dignas dessa função. Os textos são bem articulados e demonstram o conhecimento de diversas fontes, uma vez que citam bulas papais, ideias de teólogos, regras e regulamentos. Segundo Isabel Morujão (2013, p. 99), havia uma 'rede de influências' que acompanhava a entrada das religiosas nos conventos e havia uma profusão de textos de autoria de religiosas, pertencentes a um nível social elevado, e essas obras eram impressas. Todavia, existiam também as obras que permaneciam manuscritas e elas eram geralmente elaboradas por freiras de 'menos prestígio'.

Ao analisar as obras exemplares escritas por Sóror Maria do Céu, do Convento da Esperança de Lisboa, Filomena Belo (1993) questiona se a sua clausura seria realmente um espaço de devoção:

No que diz respeito ao Convento da Esperança, ficamos com a impressão de que, no século XVII e início do XVIII, este Mosteiro era não só o lugar onde podiam progredir verdadeiras vocações religiosas, mas também uma casa bem situada, ampla e ricamente decorada, onde viviam, por opção própria, algumas das mais nobres e cultas senhoras. Ou seja, mais do que um espaço destinado às vítimas do ostracismo, o Convento da Esperança parece-nos ter sido um lugar que, além de garantir segurança e respeito, oferecia a possibilidade de uma prestigiada vida social, sem no entanto desrespeitar a Regra a que estava sujeito (p. 94).

A heterogeneidade dos grupos femininos que habitavam os conventos das clarissas urbanistas demonstrava que existiam tanto aquelas mulheres que desejavam levar uma vida contemplativa e perseguiam a perfeição apontada nos escritos da época como aquelas que habitavam o espaço para ter certa liberdade em suas ações com a sociedade da época. Para essas, seguir os princípios do enclausuramento era somente uma formalidade nos seus cotidianos.

A clausura inviolável também não era uma prática nos Conventos clarianos portugueses. Talvez o caso mais conhecido de afastamento das normas claustrais aconteceu no Convento de Nossa Senhora da Conceição de Beja por Sóror Mariana Alcoforado (1640-1723), por meio da escrita das cartas de amor que encaminhou para o seu amante francês, o marquês Noel Bouton de Chamilly (1636-1715). As cartas foram publicadas na França, em 1669, e criaram grande alvoroço no universo conventual luso. Todavia, isso não foi motivo para a saída dessa religiosa do claustro, uma vez que faleceu na instituição (Mariana ALCOFORADO, [s.d.]). Segundo Saramago (1994), o referido Convento abrigava uma elite portuguesa $e$, muitas vezes, tornarse freira constituía-se como uma manutenção de status quo em suas relações sociais. Eram mulheres distantes da fé e da devoção, pertencentes às melhores famílias e que, nos conventos, pretendiam ter condições dignas de seus estatutos sociais. "Era melhor ser freira de convento rico e influente do que senhora solteira, sem dote e sem marido" (SARAMAGO, 1994, p. 82).

Para o caso da América Portuguesa, no Convento de Santa Clara do Desterro da Bahia é possível encontrar alguns documentos que atestam que as freiras estariam 'mortas' para 0 mundo. Um desses casos está presente no primeiro livro de Memórias, elaborado pela escrivã Sóror Maria de São Raimundo, uma portuguesa do Convento de Santa Clara de Évora e que fez parte do grupo fundador do Convento soteropolitano (1677). O documento apresenta como foi o traslado dela e das outras três religiosas fundadoras. Para a memorialista, todas as dificuldades enfrentadas no traslado e na construção da obra em outras terras eram agraciadas pela vontade divina e com a intencionalidade de sepultamento de diversas moças nas terras coloniais:

Deixa-se isto conhecer no modo, com que no Mosteiro de nossa Madre Santa Clara da Cidade de Évora moveu a várias Religiosas o quererem passar ao Brasil a fundarem Convento, aonde as Donzelas daquele Estado se pudessem sacrificar a Deus, e sepultar-se em vida. Via-se o Estado do Brasil já muito povoado, achavam-se nele muitas Donzelas, que tocadas de luz superior desejavam dar de mal ao mundo, e servir a Deus; mas este fervor, e desejo de servir ao Senhor esfriava em umas o temor, e perigo dos mares, que para isso haviam de passar; e em outras a falta de cabedal para navegarem, e para se recolherem. Com que as menos vinham a ser as que a todo risco buscavam Mosteiro em Portugal (Maria de SÃO RAIMUNDO apud Fr. Antonio JABOATÃO, 1858, p. 650). 
O sepultamento das jovens que adentrariam no Convento do Desterro fazia parte de um discurso inicial e institucional que previa a defesa de certa representação do mundo privado claustral. Para Antonio Castillo Gomez (2003), a representação da obra escrita pode ser compreendida como "fazer presente uma ausência, representar algo; e exibir sua própria presença como imagem, é dizer, apresentar-se representando algo, que se constitui como tal na medida em que existe um sujeito que olha (ou que lê)" (p. 112, tradução livre). O texto da primeira escrivã do referido Convento exibia a imagem que queria formar da instituição, mas também poderia indicar que havia uma ausência que deveria ser suprida: a noção da abnegação para as coisas terrenas e o encontro com Cristo/esposo por meio da morte em vida das reclusas.

No entanto, no caso da instituição baiana, é possível detectar na documentação os distanciamentos entre os princípios ordenados para a clausura feminina e encontrados nas Regras, Constituições, obras exemplares ou sermões, e a realidade conventual. Por meio da leitura da Carta Pastoral para as religiosas, escrita pelo Arcebispo da Bahia, D. Frei Manuel de Santa Ignez (1764), é possível observar a representação da clausura:

Com escândalo dos homens pios e doutos se admitem dentro destes claustros meninas e meninos, e alguns destes de mais de dez anos, e a pessoas grandes de ambos os sexos por levíssimos motivos, pois chegam a irem às celas das Religiosas a levarem Ihes algumas cousas de pouco peso negras de fora, e negros sem escrúpulo das Madres Porteiras, e se introduzem oficiais para obras desnecessárias, aos quais acompanham pessoas que tal oficio não tem.

Com o mesmo escândalo entram Médicos, Cirurgiões e Sangradores que os não são da comunidade, só por razão de estado e bizarria, sendo aliás algumas das tais pessoas indignas de se Ihes facultar esta Licença.

Não menos se escandalizam vendo franqueadas as grades a quaisquer pessoas, ainda que se não conheçam, e que nelas se admitem as que no Convento se sabe que são escandalosas, e que muitas vezes se falha com as portas abertas a mulheres e homens, aonde ou por parentesco, ou por amizade licita, ou ilícita se abraçam as pessoas de dentro com as de fora sem o mínimo remorso de consciência (Fr. Manuel de SANTA IGNEZ, 1764, s.n.).

Aos olhos do eclesiástico havia liberdade de circulação de pessoas leigas e sem permissão na clausura do Convento do Desterro, algo que já fora apontado pelo papa Bonifácio VIII quando instituiu a clausura perpétua no século XIII. O arcebispo da Bahia apontava que faltavam religiosas no Coro porque estas preferiam ficar em suas luxuosas celas, que não eram somente dormitórios, mas também espaços onde as suas escravas cozinhavam e ainda abrigavam pequenas lojas onde comercializavam produtos entre si. A cela constituía-se como uma casa independente dentro da clausura e do convento. Por outro lado, o vestuário que portavam demonstrava distinção, poder e disputas de vaidades entre as irmãs:

Do amor à vaidade que em muitas destas Religiosas predomina, e da inobservância do seu voto de pobreza são evidentes sinais o seu toucado nimiamente descomposto, e indecente às Religiosas, por lhes deixar descobertas grande parte das cabeças, e todo o pescoço: tão bem as unções com que as anciãs tingem de negro os seus cabelos já brancos, e os artifícios com que todas os compõem, e suprem alguma a falta deles para aparecerem em público com o tal toucado: os seus hábitos, e mantos certamente repreensíveis pelas caudas, pelas fitas de cor, que nas dos hábitos prendem, pelas aberturas destes anteriores, e posteriores, e pelas suas mangas de extraordinária Largura, de que tudo não pouco se escandalizam os seculares: as papeleiras, contadores, guarda roupas, e outros trastes com que muitas Religiosas ornam as suas celas: os ouros, pratas, diamantes, e outras preciosidades, de que usam contra a vontade de seus Prelados; pois algumas vestem por baixo de seus hábitos camisas bordadas, com mangas compridas e saias finíssimas, e calças e meias de seda, ligando-as comumente com fivelas de ouro cravadas de diamantes, das quais usam tão bem algumas delas nos sapatos; e chega a tanto o excesso que quando fazem alguma função pública, nela usam de sapatos todos picados, para que as pessoas assim de dentro como de fora lhes vejam a nova meia de seda cor de perola (SANTA IGNEZ, 1764, s.n.).

As freiras do Desterro usavam determinadas artimanhas para adornar os seus hábitos por meio da ampliação das caudas, de mangas mais largas para mostrarem as suas finas camisas e ainda sapatos recortados nos quais apareciam as suas meias - tudo ornado com valiosas joias. Inseridas em uma sociedade escravista, possuíam escravas, que tanto poderiam ser da 'casa' quanto particulares, sendo que, estas últimas, eram adornadas com luxo e pompa para circularem pela cidade e demonstrarem o poder de suas proprietárias. Segundo Ana Amélia Nascimento (1994), em 1775, entre "as casas monásticas femininas, era de longe o mais abusivo em quantidade de escravaria o do Desterro, com 290 escravas e 8 escravos para 81 religiosas, 7 educandas e 17 recolhidas" (p. 170). A escravaria provinha de variadas fontes: doações, descendentes de escravas que lá habitavam (crias), adquiridos por meio da compra ou recebidos das heranças das religiosas. Esses escravos podiam ser do coletivo da casa ou particulares, circulavam no espaço conventual e nas propriedades do Desterro, mas 
é necessário compreender que havia um espaço interditado para a grande maioria deles: a clausura. Algumas escravas poderiam adentrar no claustro, mas necessitavam de Breve Apostólico ou Mercê Real para essa ação (MARIA TERESA DE JESUS, 1784).

Para a sociedade conventual do Desterro, ao governo português e ao próprio papado, a reprodução dos quadros escravistas em seu interior era uma situação cômoda. Em vista disso, as irmãs conversas de véu branco não eram 'necessárias' na instituição e a documentação aponta que havia uma ampliação de vagas para as irmãs de véu preto em detrimento do número daquelas admitidas para o serviço da casa. Parece que existiria certo descaso das clarissas do Desterro em terem irmãs do véu branco, como atesta o documento abaixo, expedido pela abadessa Sóror Ana do Sacramento e redigido pela escrivã Sóror Maria Gertrudes de São José (1778):

Religiosas de Véu branco não faziam obrigação alguma, e menos serviam oficio algum deste Convento, e nas horas do Coro rezavam as contas em lugar do Oficio Divino; por cujo motivo tinham o nome de conversas, e difere as das Religiosas de Véu preto do mesmo modo que diferem nos conventos dos religiosos o leigo dos sacerdotes, e davam as ditas religiosas de Véu branco pela sua entrada para o patrimônio do Convento um conto de réis não sendo assim de utilidade alguma ao convento estas religiosas.

A consideração de inutilidade das Irmãs de véu branco não era somente pela questão dos poucos trabalhos que prestavam, mas também pelos poucos recursos que carregavam ao ingressarem no Convento do Desterro. Além disso, as aspirantes ao cargo de religiosas da instituição não desejavam portar um véu que demonstrasse condição de inferioridade em relação às demais religiosas. "Era, porém, indisfarçável o preconceito social e racial, mesmo dentro de um convento de religiosas, onde os ditames da caridade e da solidariedade deveriam coexistir com a prática do culto divino" (NASCIMENTO, 1994, p. 105).

\section{Consideraçōes finais}

Como falar de caridade e solidariedade entre as freiras do Desterro, aquelas que, segundo D. Frei Manuel de Santa Ignez (1764), nem se preocupavam com a prática do Ofício Divino e reproduziam em sua casa aspectos da sociedade local? Nessa linha, qual o sentido da clausura para essas mulheres? Embora alguns documentos relativos ao Convento de Santa Clara do Desterro da Bahia ou das diversas instituições de clarissas portuguesas apontem para os diversos desvios das religiosas, outros falam que eram freiras 'mortas' para o mundo. São as representações discursivas de um determinado espaço e período. Assim, interessava para a primeira escrivã do Desterro traçar o caminho que seria trilhado pela instituição, e a mortificação das enclausuradas era uma condição para o seu ordenamento. Por outro lado, no século seguinte, quando a instituição já estava fortalecida, é apresentado o relato do Arcebispo baiano que buscava ordenar as irregularidades da instituição.

Mesmo com todas as ordenações propostas para os claustros femininos e levando em consideração aquelas mulheres que buscavam realmente uma 'perfeição religiosa' como proposto nos discursos oficiais da Igreja Cristã, é importante salientar que os conventos se tornaram espaços de escritas, leituras e vivências que extrapolavam o instituído, propiciavam outra vida distante daquela que era requerida no seio das famílias patriarcais e acarretavam certa liberdade feminina impensável sem a representação da 'morte' para o mundo. Esta seria a 'morte' proposta para Ignez e outras tantas que ingressaram nos conventos clarianos.

\section{Referências}

ALCOFORADO, Mariana. Cartas de amor de uma freira portuguesa. Lisboa: Domínio Público, [s.d]. Disponível em http://luso-livros.net/. Acesso em 20/06/2017.

BELLINI, Lígia. "Vida monástica e práticas da escrita entre mulheres em Portugal no Antigo Regime". Revista Campus Social, Lisboa, v. 3/4, p. 209-218, 2006/2007. Disponível em http:// revistas.ulusofona.pt/index.php/campussocial/article/view/233. Acesso em 15/07/2015.

BELO, Filomena. Rellaçaõ da vida e morte da serva de Deos a venerável Madre Elenna da Crus por Sóror Maria do Céu. Lisboa: Quimera, 1993.

BRUNELLI, Delir. "Clara de Assis e o movimento religioso feminino nos séculos XII e XIII". In: SILVA, Andréia Frazão (Org.). Ciclo: a tradição monástica e o franciscanismo. Rio de Janeiro: Programa de Estudos Medievais da UFRJ; Instituto Teológico Franciscano de Petrópolis, 2002. p. 17-28.

BONIFÁCIO VIII. "Bula Periculoso, 1298". In: BONIFÁCIO VIII. Chiara d'Assisi e le sue sorelle, 1298. Disponível em https://chiaradiassisi.jimdo.com/bolla-per-la-clausura-bonifacio-viii-periculoso/. Acesso em 10/08/2017. 
CAMÕES, Luís de. Os Lusíadas. 2. ed. Lisboa: Casa de Antônio Gonçalves Impressor, 1572. Disponível em http://purl.pt/1/4/cam-3-p_PDF/cam-3-p_PDF_24-C-R0150/cam-3-p_0000_capacapa †24-C-R0150.pdf. Acesso em 20/07/2017.

COSTA, Margareth Torres de Alencar. Sóror Juana Inês de la Cruz: autobiografia e recepção. 2013. (Doutorado) - Universidade Federal de Pernambuco, Recife.

DIAS, Paula Barata. "Para uma compreensão da clausura monástica e emparedamento enquanto fenômenos históricos e religiosos". Medievalista online, Universidade Nova de Lisboa, n. 18, p. 1-32, jul. 2015. Disponível em http://www.scielo.mec.pt/scielo.php?script=sci abstract\&pid=S1646-740X2015000200008. Acesso em 15/10/2017.

DUARTE, Terezinha. "Clara de Assis, a presença feminina no movimento franciscano". Textos de História, Brasília, v. 9, n. 1-2, p. 55-73, 2001. Disponível em http://periodicos.unb.br/index.php/ textos/article/viewFile/5954/4928. Acesso em 10/08/2016.

DUBY, Georges. Ano 1000, ano 2000: na pista de nossos medos. São Paulo: EDUNESP, 1999.

FALBEL, Nashman. Heresias medievais. São Paulo: Perspectiva, 1976.

FEDERICI, Silvia. Calibã e a bruxa: mulheres, corpos e acumulação primitiva. São Paulo: Elefante, 2017.

GENNARO, Clara. "Chiara, agnese e le prime consorelle: dalle 'pauperes dominae' di S. Damiano alle Clarisse". In: Movimento religioso femminile e francescanesimo nel secolo XIII. Atti del VII Convegno Internazionale. Assis: Società Internazionale di Studi Francescani, 1980, p. 167-191.

GOMEZ, Antonio Castillo. "Historia de la cultura escrita. Ideas para el debate". Revista Brasileira de História da Educação, Campinas, v. 5, p. 93-124, jan.-jun. 2003. Disponível em http://rbhe. sbhe.org.br/index.php/rbhe/article/view/239/246. Acesso em 15/08/2017.

HATHERLY, Ana. A preciosa de Sóror Maria do Céu. Lisboa: Instituto Nacional de Investigação Científica, 1990.

HENNEAU, Marie-Elisabeth. "Regard historiographique sur des religieuses en quête d'histoire. État de la question et pistes de recherches à propos des couvents de femmes (XIII-XVIIIle s.) sur le territoire de la Belgique actuelle". Revue Belge de Philologie et d'Histoire (3-4), Bruxelas, Tome 86, p. 769-792, 2008. Disponível em http://www.persee.fr/doc/rbph 0035-0818 2008 num $86 \quad 3 \quad 7587$. Acesso em 10/11/2017.

JABOATÃO, Fr. Antonio de Santa Maria. Novo Orbe Seráfico Brasílico ou crônica dos frades menores da província do Brasil. V. II. Rio de Janeiro: Typ. Brasiliense de Maximiano Gomes Ribeiro, 1858.

JOSEPH DE JESUS MARIA. Espelho de perfeytas religiosas. Exposição da segunda regra de Santa Clara. Lisboa: Oficina de Joseph Lopes Ferreira, 1718.

LE GOFF, Jacques. São Francisco de Assis. 10. ed. Rio de Janeiro: Record, 2011.

LECLERCQ, Jean. "II monachesimo femminile nei secoli XII e XIII". In: Movimento religioso femminile e francescanesimo nel secolo XIII. Atti del VII Convegno Internazionale. Assis: Società Internazionale di Studi Francescani, 1980. p. 61-99.

L'HERMITE-LECLERCQ, Paulette. "Les femmes dans la vie religieuse au Moyen Âge. Un bref bilan bibliographique". Clio. Histoire, femmes et societé, Paris, n. 8, 2005. Disponível em https://journals. openedition.org/clio/323. Acesso em 03/12/2018.

LITTLE, Lester. "Monges e religiosos". In: LE GOFF, Jacques; SCHMIDT, Jean-Claude. Dicionário Temático do Ocidente Medieval. v. 2. Bauru: EDUSC, 2002. p. 225-242.

MANSELLI, Raoul. “'La chiesa e il francescanesimo femminile”. In: Movimento religioso femminile e francescanesimo nel secolo XIII. Atti del VII Convegno Internazionale. Assis: Società Internazionale di Studi Francescani, 1980. p. 239-261.

MARIA GERTRUDES DE SÃO JOSÉ. Certidão do Registro anexo ao Aviso régio, dirigido à Abadessa e religiosas do Convento de Santa Clara do Desterro da Bahia sobre o número de freiras de véu preto e véu branco que podiam ser admitidas naquele convento e que nunca deveria ser exercido. 11 de junho de 1778. Arquivo Histórico Ultramarino. Bahia. Eduardo de Castro e Almeida. Cx. 52, doc. 9807, 1778. 
MARIA TERESA DE JESUS. Requerimento da religiosa do convento de Santa Clara do Desterro da cidade da Bahia à rainha, solicitando permissão para ter uma escrava em sua clausura. 6 de novembro de 1784. Arquivo Histórico Ultramarino. Bahia. Cx. 186, D. 13738, 1784.

MARIN, Miguel Angelo. A perfeita religiosa: obra igualmente útil a todas as pessoas que aspirão a perfeição. Lisboa: Oficina de Simão Thaddeo Ferreira, 1789.

MORUJÃO, Isabel. Por trás da grade: poesia conventual feminina em Portugal (séculos XVI-XVIII). Lisboa: Imprensa Nacional Casa da Moeda, 2013.

NASCIMENTO, Ana Amélia Vieira. Patriarcado e religião: as enclausuradas Clarissas do Convento do Desterro da Bahia (1677-1890). Salvador: Conselho Estadual de Cultura, 1994.

NASCIMENTO, Maria Filomena Dias. "Ser mulher na Idade Média". Textos de História, Brasília, v. 5, n. 1, p. 82-91, 1997. Disponível em http://periodicos.unb.br/index.php/textos/article/view/5807/4813. Acesso em 05/10/2017.

PEDROSO, Fr. José Carlos Corrêa. Fontes Clarianas. 4. ed. Piracicaba: Centro Franciscano de Espiritualidade, 2004.

PEREIRA, Fr. José Antônio Corrêa. Cadernos de espiritualidade franciscana. Braga: Editorial Franciscana, 2011.

RUSCONI, Roberto. "L'espansione del francescanesimo femminile nel secolo XIII". In: Movimento religioso femminile e francescanesimo nel secolo XIII. Atti del VII Convegno Internazionale. Assis: Società Internazionale di Studi Francescani, 1980. p. 263-313.

SANTA CATARINA, Fr. Luis de. Sermam da conversam de S. Paulo na profissam da Madre Soror Ignez da Trindade, Religiosa do Convento de Santa Clara de Évora. Évora: Oficina da Universidade, 1673.

SANTA IGNEZ, D. Fr. Manuel. Carta pastoral dirigida às Religiosas do Convento de Santa Clara do Desterro da Cidade da Bahia, na qual se refere aos abusos e relaxações que ali se encontrara na sua visita e Ihes dá instruções rigorosas para os coibir. Bahia, 9 de junho de 1764. Arquivo Histórico Ultramarino. Seção Bahia - Eduardo de Castro e Almeida. Cx. 35, n. 6556, 1764.

SARAMAGO, Alfredo. Convento de soror Mariana Alcoforado. Real Mosteiro de Nossa Senhora da Conceição. Sintra: Colares Editora, 1994.

SCOTT, Joan. "Gênero: uma categoria útil de análise histórica". Educação e Realidade, v. 20, n. 2, p. 71-99, 1995. Disponível em: https://seer.ufrgs. br/educacaoerealidade/article/view/71721/40667. Acesso em 10/10/2017.

SILVA, Valéria Fernandes da. "Construindo a religiosa ideal: da diversidade ao modelo único". Revista de História Comparada, Rio de Janeiro, v. 3, n. 2, p. 1-28, 2009. Disponível em https:/l revistas. ufrj. br/index.php/RevistaHistoriaComparada/article/view/118. Acesso em 10/10/2017.

TÔRRES, Moisés Romanazzi. "Considerações sobre a condição da mulher na Grécia Clássica (sécs. V e IV a.C.)". Revista Mirabilia, Barcelona, v. 1, n. 1, p. 49-55, dez. 2001. Disponível em http://www.raco.cat/index.php/Mirabilia/article/view/283713. Acesso em 13/01/2018.

URSO, Carmelina. "La donna e la chiesa nel medioevo. Storia di un rapporto ambíguo". Annali della Facoltà di Scienze della Formazione, Catania, v. 4, p. 67-99, 2005. Disponível em http://ojs. unict.it/ois/index.php/annali-sdf/article/view/30. Acesso em 13/08/2017.

ZAGNI, Rodrigo Medina. "Inês é morta! A tragédia de Inês Pires de Castro entre a narrativa literária e a história". Fênix. Revista de História e Estudos Culturais, v. 5, n. 3, p. 2-17, set. 2008. Disponível em https://www.revistafenix.pro.br/revistafenix/article/view/68/59. Acesso em 05/03/201 8.

Ana Cristina Pereira Lage (ana.lage@ufvim.edu.br) Professora Adjunta do curso de História e do Mestrado Profissional Interdisciplinar em Ciências Humanas (UFVJM). Professora do Programa de Pós-Graduação em Educação (UFMG). Pós-doutora em Educação (UEM), doutora em Educação (UFMG), mestre em Educação (UNICAMP), com Licenciatura em História (UFMG). Orienta e desenvolve pesquisas na área de História da Educação, gênero e religiosidade. 
Terezinha Oliveira é Professora Titular do Departamento de Fundamentos da Educação e da Pós-Graduação em Educação na Universidade Estadual de Maringá (UEM). Pós-doutora em História da Educação (FEUSP), doutora em História (UNESP), mestre em Sociologia Política (UFSCar), graduada em História (UNESP). Orienta e desenvolve pesquisa acerca da História da Educação Medieval, com ênfase em memória, escolástica, instituições e intelectuais.

\section{COMO CITAR ESTE ARTICO DE ACORDO COM AS NORMAS DA REVISTA}

LAGE, Ana Cristina Pereira; OLIVEIRA, Terezinha. "Ignez é morta: reflexões acerca da clausura para as Irmãs Clarissas (séculos XIII ao XVIII)". Revista Estudos Feministas, Florianópolis, v. 29, n. 2, e67331, 2021.

\section{CONTRIBUIÇĀO DE AUTORIA}

Ana Cristina Pereira Lage: Responsável pela concepção, coleta e análise de dados, bem como pela elaboração, redação e discussão de resultados do manuscrito.

Terezinha Oliveira: Responsável pela análise de dados, pela elaboração, revisão e discussão dos resultados do manuscrito.

\section{FINANCIAMENTO}

Artigo produzido a partir da pesquisa de pós-doutorado intitulada "Práticas de escrita e de leitura das irmãs clarissas em Portugal e na América Portuguesa no século XVIII". Supervisão da Doutora Terezinha Oliveira (UEM). Financiamento de bolsa PNPD - CAPES (2017-2018). O presente trabalho foi realizado com apoio da Coordenação de Aperfeiçoamento de Pessoal de Nível Superior - Brasil (CAPES) - Código de Financiamento 001.

\section{CONSENTIMENTO DE USO DE IMAGEM}

Não se aplica

\section{APROVAÇĀO DE COMITÊ DE ÉTICA EM PESQUISA}

Não se aplica

\section{CONFLITO DE INTERESSES}

Não se aplica.

\section{LICENÇA DE USO}

Este artigo está licenciado sob a Licença Creative Commons CC-BY 4.0 International. Com essa licença você pode compartilhar, adaptar, criar para qualquer fim, desde que atribua a autoria da obra.

\section{HISTÓRICO}

Recebido em 01/09/2019

Reapresentado em 02/1 1/2020

Aprovado em 01/02/2021

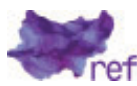

